\title{
Chieftaincy Act and Succession Disputes Resolution: A Panacea for Ensuring National Security?
}

\author{
Vincent Assanful (iD ${ }^{1}$ \\ ${ }^{1}$ Department of Religion and Human Values, University of Cape Coast, Cape Coast - Ghana.
}

\begin{abstract}
The chieftaincy institution is a revered institution and as such attempts have been made to maintain its sanctity. However, over the years, the institution has been fraught with disputes thereby bringing its image into disrepute. The chieftaincy Act, 759 (2008) was enacted by the parliament of Ghana to regulate the institution. The Act has made provisions for the resolution of disputes that have attended the institution. This article is an attempt to assess the effectiveness of the Act on the dispute resolution mechanisms of the judicial committees of the Houses of Chiefs. Using interview and textual analysis as its main instruments, the article looks at the role of the Judicial Committees of the Houses of Chiefs in dealing with the numerous succession disputes that has bedeviled the institution. The article will assess the methods the Committee uses in handling cases that come before it and how parties to the succession disputes collaborate with the Committee to dispense with the case. The article argues that if the Judicial Committee is well resourced, it will be in a position to help deal with chieftaincy succession disputes expeditiously. This would reduce the incidents of open conflicts resulting in deaths and destructions of properties thereby threatening national security.
\end{abstract}

Keywords: chieftaincy, succession disputes, national security, houses of chiefs, arbitration

\author{
Correspondence: \\ Vincent Assanful \\ Email: vassanful@ucc.edu.gh \\ Publication History \\ Received 8th April, 2021, \\ Accepted 28th April, 2021, \\ Published online 6th May, 2021.
}

(C) 2021 The Author(s). Published and Maintained by Noyam Publishers.

This is an open access article under the CCBY license (http://creativecommons.org/licenses/by/4.0/).

\section{INTRODUCTION}

The Chieftaincy institution is one of the most revered and sacred institutions in Ghana. This institution has survived over the years despite the challenges it faced during the colonial era and still facing in the current political dispensation. ${ }^{1}$ Despite these challenges, the institution has persisted to this day. The resilience of the Chieftaincy institution has surprised adherent of the modernisation school of thought. This school of thought holds the view that with increasing urbanisation, industrialisation and the emergence of a multi-ethnic society and an educated elite less rooted in their traditional beliefs and practices, the Chieftaincy institution is bound to gradually lose its relevance within the African context. ${ }^{2}$ However, this has not been the case as the Chieftaincy institution contrary to the position of the modernisation theorists has seen a resurgence in most African countries in the post-colonial period. ${ }^{3}$

The institution has, however, been criticised by some as antiquated and one that must be done away with. The debate on the relevance of the Chieftaincy institution in post-colonial Ghana has raged for a very long time. The abolitionists feel it has lost its relevance while the anti-abolitionists believe the Chieftaincy institution is as relevant today as it has ever been. For the abolitionists they argue that the Chieftaincy institution should be abolished for the following reasons:

\footnotetext{
1 Kwame Boafo-Arthur, "Chieftaincy in Ghana: Challenges and Prospects in the $21^{\text {st }}$ Century." In Chieftaincy in Ghana: Culture, Governance and Development, eds. I. Odotei and A.K. Awedoba (Accra: Sub-Saharan Publishers, 2006), 145

2 Anamzoya Alhassan and Steve Tonah, "If You Don't Have Money Why Do You Want to Be Chief? An Analysis of the commercialization of Justice in The Houses of Chiefs in Ghana," Ghana Social Science Journal 7, no 1 (2010): 1.

3 Pierliugi Valsecchi, "He who sets Boundaries: Chieftaincy as a necessary institution in modern Ghana," Department of Communication Working Paper, no 3 (2007): 1-2;
} 
1. Traditional rulers have neither power nor authority and therefore no duties to perform

2. They cost the public money which is given to them as allowances

3. It is wrong for a few people to be arrogated the power to hold public office giving them the right to public respect and a greater share in certain resources, such as land than others just because they happen to be members of certain families

4. The litigation that has engulfed the institution is wasteful of public funds and also distracts the attention of the public and of the government from matters of greater importance.

5. The control of lands by the traditional authorities prevents changes in the system of land rights, which would make land easier to acquire. ${ }^{4}$

The abolitionists have been countered by the retentionists who are of the opinion that the chieftaincy institution is still relevant. They advance these reasons to support their position:

1. The traditional rulers still direct community development in the same way as they did during the colonial period

2. The traditional rulers provide a link between their communities and the government helping to attract developmental projects to the community

3. Traditional rulers though do not have the authority to hear cases as the modern courts, still help to keep law and order in their communities and many people access the traditional courts to have their disputes on land, in marriage and in between families settled. ${ }^{5}$

Despite these arguments, the institution has survived and continues to play various roles to ensure the development of communities. A traditional ruler noted that "frankly speaking, any attempt to abolish chieftaincy which embodies the soul, culture, authority, socio-economic and political lives of the local people, would not be easy." The Chieftaincy institution has contributed a lot to the development of the country as it is seen as a development agent. The institution has evolved from the time when chiefs led their communities to fight wars of conquest to the present situation where the fight is now against poverty, filth, diseases, unemployment, lack of basic social amenities and so on.

The chieftaincy institution is, however, not spared of constant criticism of being the cause of wanton destruction of properties and needless loss of lives. Many communities have been hit with chieftaincy disputes that have led to the destruction of properties and loss of lives thereby threatening national security. According to the former Minister of Chieftaincy and Religious Affairs, Mr. Kofi Dzamesi, there are about 352 Chieftaincy disputes in the country. ${ }^{7}$ Some victims have been internally displaced putting pressure on the government to provide them with shelter. In an attempt to find a lasting solution to the incessant conflicts that have afflicted the chieftaincy institution, the state in 2008 enacted the Chieftaincy Act to bring some sanity and peace to the chieftaincy institution. This article is an attempt to assess the Chieftaincy Act, 759 (2008) and its role in resolving succession disputes in the country. In the sections that follow, the paper discusses the methodology, Chieftaincy succession disputes in Ghana, Chieftaincy Act, 2008 and succession disputes resolution.

\section{METHODOLOGY}

This article adopted the qualitative research approach in the data gathering procedure and analysis. An unstructured interview guide was used to elicit information from respondents. The respondents were purposively sampled and interviewed. The direct material for this article is mainly, but not exclusively primary since relevant secondary sources were cited to help guide the discussion.

\section{Chieftaincy succession disputes in Ghana}

Ghana has over the years seen numerous chieftaincy disputes. The various disputes that have bedevilled the chieftaincy institution have come from two main sources. Conflicts that relate to succession to a stool or skin and conflicts that relates to destoolment or deskinment of a chief. This article discusses conflicts arising from succession disputes. The chieftaincy institution as noted earlier, is considered one of the prestigious institutions in Ghana. Chiefs command a lot of respect in their communities. They have access to a lot of resources thereby making them important development agents. The prestige associated with the Chieftaincy institution has led to several people showing interest in being enstooled or enskinned as chiefs in the various traditional areas of the country. ${ }^{8}$

\footnotetext{
Kwame Arhin, Traditional rule in Ghana: Past and Present (Accra: SEDCO Publishing, 1985): 126-127

Arhin, Traditional rule in Ghana, 129-131

GNA, "The Chieftaincy Institution is still Relevant," Ghana News Agency, April 26, 2010

Nana Yaw Barimah, "Find Solutions to Chieftaincy Conflicts- Kofi Dzamesi," www.graphic.com.gh, 2017

Steve Tonah, "The Politicisation of a Chieftaincy Conflict: The Case of Dagbon, Northern Ghana,” Nordic Journal of African Studies, 21 no. 1 (2012): 1.
} 
Chieftaincy succession disputes are found all over Ghana. In a study by Kendie, Osei-Kufour and Boakye, they found out that chieftaincy conflicts ${ }^{9}$ were found in all the parts of Ghana. In their analysis of the various geographical zones of Ghana, Chieftaincy disputes were found in Northern, Middle and Southern zones of the country. This is confirmed by a former Minister of Chieftaincy and Religious Affairs, Mr Kofi Dzamesi, who in an address to inaugurate the Asuboa Traditional Council in the Ashanti Region of Ghana stated that as at 2017, the country has recorded some 352 Chieftaincy disputes nationwide. ${ }^{10}$ Examples of these conflicts can be found in the Northern part of Ghana where two or more gates lay claim to a chieftaincy position or title. ${ }^{11}$ In the Southern part of Ghana, several of such disputes have also been reported. Notable among these are the Ga Mashie succession dispute. ${ }^{12}$ Two persons are claiming legitimacy to the stool as the Ga Mantse. Other cases that can be mentioned include the Wenchi, Odomase No 1, Akyem Kotoku, Enyan Denkyira and Effutuakwa Traditional Areas. ${ }^{13}$ Various reasons have been advanced for the protracted Chieftaincy succession disputes witnessed all over the country.

Some of the reasons addressed in the literature for the Chieftaincy conflicts include the attitude of Kingmakers who circumvent the laid down customary rules in the selection of a legitimate royal to occupy a vacant stool or skin. ${ }^{14}$ Hagan on the other hand gives three main reasons why succession disputes may occur. Among these are people not qualified but scheming to be made chiefs through financial inducements, the increase in the number of potential claimants to the stool or skin and the fierce contest that may ensue as to who should be made a chief..$^{15}$ These reasons were confirmed by an elder of the Assin Attandasu Traditional Area in the Central Region, Opanin Ennin, who in an interview opined:

Most of the time it is about money. The Kingmakers may be the cause of these disputes. Some may go and collect money from a candidate promising him the stool. Some of these candidates may not be the rightful persons to be made chiefs and if you have a kingmaker collecting money from such a person, it could lead to disputes. Others may not be from the royal family but may scheme and try to be made chiefs. These may also lead to succession disputes. ${ }^{16}$

The views expressed by the elder show how the affluent and the powerful in society use their position to try to influence the enstoolment processes. This is often resisted by the rightful royals and thus, lead to disputes. It is in the attempt to forestall such disputes and its attendant loss of lives and properties that the state in 2008 enacted the Chieftaincy Act, Act 759.

\section{Chieftaincy Act (2008), Act 759 ${ }^{17}$}

The 1992 constitution of Ghana guarantees the Chieftaincy institution. Article 270 (2a) debars Parliament from enacting any law which:

(a) Confers on any person or authority the right to accord or withdraw recognition to or from a chief for any purpose whatsoever; or

(b) In any way detracts or derogates from the honour and dignity of the institution of chieftaincy. ${ }^{18}$

To give legislative backing to the Chieftaincy institution, Act 759 was enacted by the Parliament of Ghana to bring the institution into conformity with the constitution of Ghana. The Chieftaincy Act of 2008 is the third of such Acts to be enacted by the state. The previous two were Chieftaincy Act 1961, Act 81 and Chieftaincy Act 1971, Act 370. Act 759 of 2008 was enacted to bring Act 370 into conformity with the 1992 constitution. ${ }^{19}$ The coming into force of Act 759 has brought some sense of peace and stability to the chieftaincy front. A discussion of the various sections of the Act follows.

The Act makes provision for the establishment of the various Houses of Chiefs. From the National to the

\footnotetext{
Stephen B. Kendie, Patrick Osei-Kufuor and Kwaku Adutwum Boakye, eds., Spatial analysis of violent conflicts in Ghana: $2007-2014$ (Cape Coast: Faculty of Social Sciences, 2014).

10 Ghana Business News, “352 chieftaincy disputes remain unresolved in Ghana.” https://www.ghanabusinessnews.com/2017/06/01/352-chieftaincy-disputesremain-unresolved-in-ghana/. Accessed 27/04/2021.

11 Tonah, The Politicisation of a Chieftaincy Conflict, 2.

12 Paul Acheampong Boakye and Daniel Beland, "Explaining chieftaincy conflictusing historical institutionalism: A case study of the Ga Mashie chieftaincy conflict." Africa Studies, 78, no 3 (2019):413.

13 Isaac Owusu-Mensah; W, Asante and W.K. Osew, "Queen Mothers: The unseen hands in Chieftaincy conflicts among the Akan in Ghana: Myths or reality," The Journal of Pan African Studies, 8 no. 6 (2015): 8-10

14 Owusu-Mensah; Asante and Osew, Queen mothers, 6

15 George Panyin Hagan, "Epilogue: The Way Forward-New Wines and Broken Bottles" In Chieftaincy in Ghana: Culture, Governance and Development, eds. I. Odotei and A.K. Awedoba (Accra: Sub-Saharan Publishers, 2006), 664

16 Opanin Ennin, interview granted the researcher, April, 82017 . He is the curator of the Attandasu Palace Museum.

17 Ghana, Chieftaincy Act, Act 759 (Accra: Assembly Press, 2008), 4

18 Ghana, Constitution of the Republic of Ghana (Accra: Assembly Press, 1992), 164

19 Siedu Danaa, "Using the Chieftaincy Act to resolve nagging issues," Ghanaian Times, 10 May, 2014. Accessed May, 28, 2018. http://www.ghanaian times.com
} 
Regional Houses of Chiefs. The Act also gives recognition to the Traditional and Divisional Councils. The Act prescribes the various roles and functions of the Houses of Chiefs and Traditional Councils. Section 3 (1) of the Act gives the function of the National House of Chiefs. Among these are:

(a) advise a person or an authority charged with a responsibility under the Constitution or any other law for any matter related to or affecting chieftaincy,

(b) undertake the progressive study, interpretation and codification of the customary law with a view to evolving, inappropriate cases, a unified system of rules of customary law, and compiling the customary laws and lines of succession applicable to each stool or skin. ${ }^{20}$

The functions of both Regional Houses and Traditional Councils are equally spelt out in sections 9 and 21. The Act again gives original jurisdiction on all chieftaincy related cases to the Houses of Chiefs and the Traditional and Divisional Councils. The National House of Chiefs has both original and appellate jurisdictions on Chieftaincy succession or destoolment disputes. The Regional Houses of Chiefs in section 26 equally have original and appellate jurisdiction on chieftaincy matters. While they have original jurisdiction on matters concerning paramount stools and skins, they have appellate jurisdiction on appeals from the Traditional Councils. To enable the Houses of Chiefs and the Traditional Councils to adjudicate on chieftaincy succession or destoolment cases, the Act has allowed to be created Judicial Committees to sit on such disputes involving chieftaincy matters. The Act in section 30 has also made provision for customary arbitration of chieftaincy succession and destoolment disputes. The next section discusses how the Act can be used to resolve Chieftaincy succession disputes.

\section{Act 759 and Chieftaincy succession dispute resolution}

The Chieftaincy Act as stated earlier, has given the various Traditional Councils and Houses of Chiefs original jurisdictions on matters of Chieftaincy disputations in the country. The Act has, as earlier alluded, allowed to be created for each Traditional Council and House of Chiefs a Judicial Committees to sit and adjudicate on Chieftaincy succession and destoolment disputes. Section 31 of the Act outlines the proceedings of the Judicial Committees.

\section{Adjudicating methods of the Judicial Committees}

Section 31 of the Act regulates the activities of the Judicial Committees of the Houses of Chiefs. 31 (1) of the section states the procedures for the hearing of any challenge. It states: "A Judicial Committee may receive in evidence any matter including hearsay which tends to prove or disprove a fact relevant to the subject matter before the Committee." ${ }^{21}$ The Committee is mandated by the Act to apply the High Court rules in its adjudicating procedures. The Committee may do all or any of the following:

(a) make presumptions of law or fact,

(b) take cognisance of matters which are so notorious or so clearly established that evidence of their existence is not necessary,

(c) draw inferences from facts already in evidence. ${ }^{22}$

The method used by the Committee in adjudicating cases is fair as it gives both parties to the dispute the right to represent themselves or by a counsel. Section 31 (4) is clear on the legal representation. It says:

A party to proceedings before the Judicial Committee may appear in person or by a lawyer and any other person required to appear either in person or with leave of the Committee by a lawyer. ${ }^{23}$

The succession dispute involving sub-chiefs begin at the Traditional Council. Any appeal emerging from the proceedings of the Traditional Council lie with the Judicial Committee of the Regional House of Chiefs. In the case where the succession disputes involve a paramount stool or skin, the Judicial Committees of the Regional Houses of Chiefs have the original jurisdiction to adjudicate on the dispute and any appeal then, will be sent to the judicial committee of the National House of Chiefs. When parties are dissatisfied with the ruling of the Judicial Committee of the National House of Chiefs, they have the right to appeal to the Supreme Court of Ghana. Article 273 (6) of the 1992 constitution of Ghana says:

An appeal shall lie of right in respect of any cause or matter dealt with by the Judicial Committee of the National House of Chiefs under clause (5) of this article to the Supreme Court. ${ }^{24}$

\footnotetext{
Chieftaincy Act 759, 6 .

Chieftaincy Act, 16.

2 Chieftaincy Act, 16.

3 Chieftaincy Act, 16.

Article 273 (6) of the constitution of Ghana.
} 
The Supreme Court has been called upon several times to settle chieftaincy succession disputes when its jurisdiction was invoked by a disputing party. The recent case was the final ruling the Supreme Court delivered when its jurisdiction was invoked by one of the disputing parties as to which gate was the legitimate gate to enskin a Bimbilla Naa (this would be discussed in detail later). The ruling of the Supreme Court was in conformity with section 24 of the Chieftaincy Act 2008. What the section does is to clarify that the Supreme Court is the only body that has the right to look into a decision of the judicial committee of the National House of Chiefs.

Despite the fact that these disputes could be expensive and, on some occasions, destructive, the Houses of Chiefs have helped in ensuring that these disputes are settled amicably. ${ }^{25}$ Despite the cost involved in litigating chieftaincy disputes, the role of the Judicial Committees in handling such cases has brought some semblance of peace to the communities affected by such disputes. The importance of the Judicial Committees came to the fore in the interviews with some personnel of the Houses of Chiefs. Mr. Oppong of the National House of Chiefs in Kumasi remarked:

The Judicial Committee helps a lot. Whenever cases are brought here, the litigants cease fire and await the final judgment of the committee. Just as the normal courts operate, no one can take any action so far as a case was before the judicial committee for adjudication. ${ }^{26}$

The views of Mr. of Oppong were confirmed by Mr. Mamah, a Senior Assistant Registrar with the Central Regional House of Chiefs who had this to say:

Without the judicial committee, disputes would not be resolved. The Committee is very important since its absence would have led to chaos. Its presence has led to the amicable settlement of chieftaincy disputes. ${ }^{27}$

Brobbey makes a similar point when he opines that "the Judicial Committee of the Traditional Council is the appropriate forum to pursue a dispute concerning a chief or queen mother, stool or skin below the status of the Asantehene, a paramount chief, a paramount queen mother, a paramount stool or a paramount skin." ${ }^{28}$ Knowing that the judicial processes of resolving Chieftaincy succession disputes could be expensive and time consuming, the Act has made provision for customary arbitration of disputes.

\section{Customary arbitration}

The Chieftaincy Act 2008 has made provisions for customary arbitration of chieftaincy succession and destoolment disputes. As indicated earlier, section 30 makes arbitration an integral part of the settlement processes. An Assistant Registrar at the Central Regional House of Chiefs, Gloria Banfor explained the arbitration processes:

Arbitration is when both parties agree that a chief should settle their case through arbitration. In this case if someone petitions the House and opts for arbitration, the House would have to seek the consent of the other party if they would want the case to be settled through arbitration. There is no deposit of money for the arbitration process. The parties however, are made to pay some money to be given to the chiefs as allowance. The arbitration functions as alternative dispute resolution mechanism. No lawyer is needed. If a party disagrees, the arbitration process will not commence..$^{29}$

Brobbey discussing the arbitration processes of the Houses of Chiefs had this to:

By section 30 of Act 759, the law now recognises the power of chiefs to settle disputes by customary arbitration, subject to the conditions that the person presiding at the arbitration is a chief, that the parties' consent to the chief settling the dispute in his capacity as customary arbitrator and that the dispute can be settled by applying customary law. ${ }^{30}$

The Chieftaincy Act 2008, Act 759 has been put together to help deal with any dispute that may result from any succession or destoolment crisis. Through the rulings of the judicial committees, the Act has helped in ensuring that chieftaincy succession disputes are amicably settled.

\section{Discussion}

The Chieftaincy institution has not been free from disputations. The prestige and status associated with the institution, has attracted a lot of interested parties. Some of these people may not be eligible to be made chiefs since they may not be from any of the royal houses or gates. Others, using their wealth, have succeeded in compromising the nomination processes. Royals who may be poor and not wanting to lose their stools and skins to imposters have risen to challenge

\footnotetext{
${ }^{5}$ Alhasan and Tonah, if you don't have money why do you want to be a Chief? 11

Mr. Oppong, interview granted the researcher, May 7, 2017

Mr. Mamah, interview granted the researcher, May, 9, 2017

S.A. Brobbey, The law of Chieftaincy in Ghana (Accra: Advanced Legal Publications, 2008):254

Gloria Banfor, interview with the researcher, May, 9, 2017

Brobbey, The Law of Chieftaincy in Ghana, 241.
} 
such nominations thereby leading to disputes. It is the bid to forestall such conflicts that the Chieftaincy Act, 2008 was enacted by the parliament of Ghana. The Act, as an important piece of legislation, if well harnessed, can be used to deal with Chieftaincy succession disputes thereby ensuring national peace.

Chieftaincy succession disputes have engulfed the nation causing well-meaning Ghanaians to call on the National House of Chiefs and government to ensure that the numerous disputes are amicably resolved. This is important as the numerous disputes have led to the retardation of development in the affected areas. The former Minister of Chieftaincy and Religious Affairs, Mr. Kofi Dzamesi commenting on the destructive nature of chieftaincy disputes remarked "chieftaincy disputes had retarded progress and development in many communities and created disaffection and intolerance in society. ${ }^{31}$

The National House of Chiefs equally issued a statement to express their worry over the Bimbilla and Ga Mashie chieftaincy disputes. The statement "appealed to the parties to use appropriate legal channels to get the disputes resolved. They should allow the peace to prevail for the common good of the people they represent. House was upset about the loss of lives, destruction to property and displacement of people by the renewed clashes and called on all to cooperate with the security agencies." 32

The negative effects of such conflicts cannot be quantified. Many lives and properties have been lost to these incessant disputes. In 2017, Citi news reported that residents of Oshieyie a community close to Kokrobite in the Greater Accra Region of Ghana had to flee their community to neighbouring communities as chieftaincy disputes escalated leading to the loss of one life. The effects on the economic life of the people are equally worrying. A resident of Oshieyie, a fishing community, remarked:

As I sit here, it's time to go fishing and I can't. This will not only affect the men. It will affect the women too. This is because, if we don't go fishing, they won't get fish to sell. There are schedules we follow and we can't keep to the schedules because of the violence that goes on here every day. We are going hungry and school is about to reopen. Where will we get money to pay for our children's school fees. ${ }^{33}$

In other parts of the country the effects of the Chieftaincy succession dispute have been reported in both the media and scholarly works. The disputes have affected economic activities in the affected communities. Women have had their economic activities truncated by these conflicts especially in Northern Ghana. These disputes have led to high cost of doing business in the affected areas. ${ }^{34}$ The effects of Chieftaincy succession conflicts on the economy in the affected areas have necessitated the need for legislation to be enacted to help ameliorate the security situation of the affected areas in particular and the country in general. It is for this reason that the Chieftaincy Act 2008 becomes important and if well utilised could become a panacea for dealing with these disputes thereby ensuring national security.

The Chieftaincy Act has established the judicial committees at all levels of the chieftaincy hierarchy from the Traditional Council to the National House of Chiefs. The Act has set the various jurisdictions of the various Judicial Committees. In matters that affect a divisional or a chief of a community of a Traditional Area, the Judicial Committee of the Traditional Council has the original jurisdiction to determine the case. Aggrieved parties who are not satisfied with the ruling of the Judicial Committee have the right to appeal to the Judicial Committee of the Regional House of Chiefs. The parties have the right again to appeal to the National House of Chiefs if they are not satisfied with the ruling of the Regional House of Chiefs. Parties have the right where they are still not satisfied to go to the Supreme Court for redress. The recent ruling on the Bimbilla chieftaincy succession would be used to exemplify the importance of the Chieftaincy Act 2008 in addressing chieftaincy succession disputes.

The Supreme Court of Ghana on May 23, 2018 settled the Bimbilla chieftaincy succession dispute as to the rightful occupant of the Bimbilla Skin. The Supreme Court had to come in when the matter travelled from the Traditional Council, Northern Regional House of Chiefs and National House of Chiefs. The Bimbilla Chieftaincy succession disputes started when two claimants to the skin, Naa Andani Dasana Abdulai and Naakpa Naa Salifu Dawuni emerged. Per the provisions of the Chieftaincy Act, 2008 section 29 (1) states:

Subject to this Act, a Traditional Council has exclusive jurisdiction to hear and determine a cause or matter affecting chieftaincy which arises within its area, not being one to which the Asantehene or a paramount chief is a party.

The case was first adjudicated by the Nanumba Traditional Council with the Nayiri, King of Nanumba, presiding. The ruling went in favour of the Naa Andani family. Not satisfied with the ruling of the Nayiri, the Naakpa Naa family appealed to the Northern Regional House of Chiefs. The Judicial Committee of the House affirmed the ruling of the

\footnotetext{
Nana Yaw Barimah," Find solutions to Chieftaincy disputes-Kofi Dzamesi," Daily Graphic, May 31, 2017. www.graphic.com.gh. Accessed May 28, 2018

32 Dorothy Frances Ward, "NHC upset about flare up of Bimbilla and Ga Chieftaincy conflicts." Ghana News Agency, February $14,2017$. www.ghananewsagency.org. Accessed May 28, 2018

33 Philip Nii. Lartey, Chieftaincy disputes disrupting our lives-Oshiyie residents. Citifmonline, August 8, 2017. www.citifmonline.com. Accessed May 28, 2018

34 Kaderi Noagah Bukari "Conccomitant of conflict and consensus: A case of a chieftaincy succession in Ghana". Peace and Conflict, 23 no 1 (2016)
} 
Nayiri to the effect that Naa Andani was the rightful heir to the Bimbilla skin. In conformity with the section 24 of the Act, the Naakpa Naa faction proceeded to the Supreme Court on appeal. On Wednesday, May 23, 2018, the Supreme Court affirmed the National House of Chiefs' 2014 ruling which also declared the Naa Andani family as the legitimate rulers. The court averred in a ruling read by Justice Gabriel Pwamang that the late Naa Andani Dasana had been lawfully enskinned as ruler of Bimbilla. ${ }^{35}$

From the above it can be seen that the various provisions in the Act have made it possible for aggrieved parties to any Chieftaincy succession to exhaust all legal avenues to seek redress if they so feel aggrieved with any ruling. This is important as litigants get to know that they have not been cheated out of what they consider to be their rightful claim to a stool or skin. The ruling by the Supreme Court on the Bimbilla dispute has brought some semblance of peace to the restive area as people waited anxiously to see where the ruling will go.

Another important dispute resolution mechanism aside the laborious and expensive judicial dispute resolution mechanism the Chieftaincy Act has made provision for is the customary arbitration. Customary arbitration has been defined in Pong v Mante [1964] GLR 593 at 596 per Lassey J as:

The ... practice whereby natives of this country constitute themselves into ad hoc tribunals popularly known and called arbitrations for the purposes of amicably settling disputes informally between them or their neighbours (which) has long been recognized as an essential part of our legal system; provided all the essential characteristics of holding a valid arbitration are present, the courts will undoubtedly enforce any valid award published by such ad hoc bodies. ${ }^{36}$

The Alternative Dispute Resolution Act, 2010 Act 798 has also defined customary arbitration as "the voluntary submission of a dispute, whether or not relating to a written agreement for a final binding determination under Part Three of this Act." ${ }^{37}$ Customary arbitration has helped to bring customary law and practice within the mainstream legal statutes and procedures in Ghana. ${ }^{38}$ One important feature of the customary arbitration system is that it is less expensive. Parties to the arbitration need not engage the services of a lawyer. The fees to be paid are not much. The arbitration is chaired by a chief selected with the concurrence of the disputing parties. Customary arbitration is an adjudicatory process. The arbitrators listen to both parties to the disputes and then decide on the judgement or award to be handed to the parties involved. ${ }^{39}$

Customary arbitration has been used to resolve a lot of Chieftaincy succession disputes in Ghana. In a meet-thepress series, a former Minister of Chieftaincy and Culture, Mr. Alex Asuma-Ahensah noted that the use of customary arbitration has helped to ensure peace and harmony in the country. He explained further:

It is worth noting that without the intervention of Nananom in settling disputes out of court, the Houses of

Chiefs and the civil courts would have been inundated with more cases than they could handle. ${ }^{40}$

Customary arbitration was again used by the chiefs and elders to settle a long-standing Chieftaincy dispute between the people of Kpetoe and Afegame in the Agortime Traditional Area of the Volta Region of Ghana. The dispute came about as a result of a misunderstanding between the two main gates of Agortime, namely the Akumase at Kpetoe and the Bedzekpenu at Afegame, leading to the situation where the Akumase gate was always producing the Paramount Chief, a development which created hatred between the two communities over the years. ${ }^{41}$ During the customary arbitration, Nene Nuer Keteku said that:

he was not going to determine who was at fault, but narrated what resulted in the protracted dispute, and after a brief history of events leading to the dispute between the two communities, the Paramount Chief finally blamed the two communities for wrongful misinterpretation of events of the past, which was necessitated by their elders, most of whom have died many years back. ${ }^{42}$

The use of customary arbitration was equally present in settling the chieftaincy succession dispute of the Bulsa of Upper East Region of Ghana. According to Bukari, the Bulsa have adopted a strict adherence to laid-down tradition and use of traditional methods of dispute resolution as well as the willingness of the winner to reach out to the losers. He continues: Through the use of the rites of the earth cult and negotiation by elders, conflicts are settled and the disputants who

\footnotetext{
35 Joyce Danso, "Supreme Court delivers judgement in Bimbilla Chieftaiancy dispute." Ghana News Agency, May 23, 2018. www.ghananewsagency.org. Accessed May 28, 2018

36 Brobbey, The law of Chieftaincy in Ghana, 365-366

37 Ghana, Alternative Dispute Resolution Act 798 (Accra: Assembly Press, 2010): 40

Emelia Onyema, “The new Ghana ADR Act 2010: A critical overview.” Arbitration Journal, 28 no. I (2012): 10

Brobbey, The law of Chieftaincy in Ghana, 367

GNA, Chiefs have ensured peace in the country through customary arbitration-Asum Ahensah. Ghana News Agency, October $27,2010$. www.businessghana.com. Accessed May 28, 2018

41 Samuel Agbewode, “ADR used to settle 89-year-old chieftaincy dispute between Kpetoe , Afegame.” Ghanaian Chronicle, July $29,2009$. www.modernghana.com. Accessed May 28, 2018

42 Agbewode, ADR used to settle 89-year-old chieftaincy dispute, para. 7
} 
challenge the election agree to peaceful resolution of the conflicts. ${ }^{43}$

The application of customary arbitration by the chiefs and people of the various traditional areas plagued by succession disputes has helped to reduce the number such disputes in the country. From the views shared by Mr. Alex Asuma-Ahensah, a former Minister of Chieftaincy and Culture, the use of customary arbitration has proven to be instrumental in ensuring peaceful handling of chieftaincy disputes. This view is confirmed in how a ninety-sixyear-old chieftaincy conflict was amicably resolved using customary arbitration by the Chiefs and people of Agortime Traditional Area.

This study has shown that the use of the Chieftaincy Act 2008 has made it possible for succession disputes affecting the chieftaincy institution to be amicably settled in the various traditional areas of Ghana experiencing such conflicts. The various provisions in the Act that deals with succession and destoolment disputes are important if the security of the state is to be maintained. The Act, allowing disputants to appeal any verdict reached by a Judicial Committee, is key to ensuring that all avenues are exhausted by the various parties to a chieftaincy succession dispute.

The Supreme Court according to the Act is the final arbiter in any chieftaincy dispute. As was noted in the Bimbilla succession dispute, the Supreme Court had to settle the issue as to which family had the right to the Bimbilla skin. In the aftermath of the Supreme Court ruling, a spokesperson for the Naakpa Naa family said, though they were sad with the outcome of the ruling, they nevertheless accepted and would abide by the decision of the Court. ${ }^{44}$

\section{CONCLUSION}

The paper in contributing to the discussion on Chieftaincy disputes in Ghana achieved the following objectives. The effectiveness of the Chieftaincy Act, 2008 was dealt with. The roles of the Judicial Committee of the Houses of Chiefs were discussed. the methods used by the Committee in adjudicating disputes were also discussed and finally, the need to resource the Judicial Committees to effectively deliver on their mandate was discussed.

The Chieftaincy Act, 2008 has made it possible for succession disputes to be settled either through the Judicial Committees of the Houses and ultimately by the Supreme Court, if the apex court is called upon to settle the dispute. Using the Chieftaincy Act has resulted in the nation enjoying some semblance of peace in those restive areas. It is the contention of this paper that but for the passage of the Chieftaincy Act, 2008, the number of chieftaincy disputes in the country would have been more than the 352 cases cited by Mr. Kofi Dzamesi, a former Minister of Chieftaincy and Religious Affairs. The Chieftaincy Act (20008), Act 759, I dare say has helped to ensure peace and if well harnessed can guarantee national security.

This paper has made forcefully the point that the use of customary arbitration has been key in ensuring that succession disputes are amicably settled with little financial cost to the disputants. The customary arbitration process guaranteed by the Act is important since it required the agreement of both parties to the dispute. The House of Chiefs is then permitted to appoint one of their own with the concurrence of the disputants to help settle this dispute. The resort to customary arbitration is less expensive and it helps to expeditiously resolve chieftaincy succession disputes. As Mr. Alex Asuma-Ahesan indicated, without the resort to customary arbitration by the Houses of Chiefs with the concurrence of the disputing parties, the Houses of Chiefs and the courts would have inundated by several cases.

In an earlier study by Alhassan and Tonah, ${ }^{45}$ they found out how expensive the judicial processes at the Houses of Chiefs could be. One area that stalls expeditious adjudicating of cases is the filling fees both parties to pay. If the fees are absolved by the state or reduced, the processes will not be left in the of the hands of the highest bidder as evidenced in the study by Alhassan and Tonah. The paper recommends that the Judicial Committees, in the light of the work they do to keep the peace of the country, be given a special budgetary allocation so they could promptly pay the panel members and retain Counsels, without whom the work of the Committee cannot proceed.

\section{ABOUT AUTHOR}

Vincent Assanful (PhD) is a Senior Lecturer in the Department of Religion and Human Values,University of Cape Coast - Ghana.

\section{BIBLIOGRAPHY}

Agbewode, Samuel “ADR used to settle 89-year-old chieftaincy dispute between Kpetoe, Afegame." Ghanaian Chronicle, July 29, 2009. https://www.graphic.com.gh/news/politics/find-solution-to-chieftaincy-disputes-kofi-dzamesi.html

\footnotetext{
43 Bukari, "A concomitant of conflict and consensus: A case of a chieftaincy succession in Ghana, 21.

44 Nathan Gadugah, "Nakpaa Naa family sad but accepts SC ruling on Bimbilla skin.” May 23, 2018. www.myjoyonline.com. Accessed May $28,2018$.

45 Alhassan and Tonah, if you don't have money, 10.
} 
Akrong, Abraham "Religion and Traditional Leadership in Ghana." In Chieftaincy in Ghana: Culture, Governance and Development, edited by. Irene Odotei and Albert K. Awedoba, 193-212. Accra: Sub-Saharan Publishers, 2006.

Alhassan, Anamzoya and Tonah, Steve. "If You Don't Have Money Why Do You Want to Be Chief? An Analysis of the commercialization of Justice in The Houses of Chiefs in Ghana," Ghana Social Science Journal 7, no 1 (2010): $1-13$.

Arhin, Kwame. Traditional rule in Ghana: Past and Present. Accra: SEDCO Publishing, 1985.

Assanful, Vincent. The role of the indigenous Assin Indigenous Religion in the Inheritance and Succession Practices of the Assin. Ph.D., University of Cape Coast, 2017.

Barimah, Nana Yaw "Find Solutions to Chieftaincy Conflicts- Kofi Dzamesi," Daily Graphic. 2017. https://www.graphic.com.gh/news/politics/find-solution-to-chieftaincy-disputes-kofi-dzamesi.html

Boafo-Arthur, Kwame. "Chieftaincy in Ghana: Challenges and Prospects in the $21^{\text {st }}$ Century." In Chieftaincy in Ghana: Culture, Governance and Development, edited by. Irene Odotei and Albert. K. Awedoba, 145-168. Accra: SubSaharan Publishers, 2006.

Brobbey, S.A. The law of Chieftaincy in Ghana. Accra: Advanced Legal Publications, 2008.

Bukari, Kaderi Noagah. "A concomitant of conflict and consensus: A case of a chieftaincy succession in Ghana." Peace and Conflict Studies, 23 no. 1 (2016).

Busia, Kofi Abrefa. The Position of the Chief in the Modern Political System of Ashanti: A Study of the Influence of Contemporary Social Changes on Ashanti Political Institutions. London: Oxford University Press, 1968.

Danaa, Siedu "Using the Chieftaincy Act to resolve nagging issues," Ghanaian Times, 10 May, 2014. http://www.ghanaiantimes.com.gh/using-the-chieftaincy-act-toresolve-nagging-issues/

Danso, Joyce "Supreme Court delivers judgement in Bimbilla Chieftaiancy dispute." Ghana News Agency, May 23, 2018. http://www.ghanaiantimes.com.gh/using-the-chieftaincy-act-toresolve-nagging-issues/

Gadugah, Nathan. "Nakpaa Naa family sad but accepts SC ruling on Bimbilla skin.” Myjoyonline, May 23, 2018. https://www.myjoyonline.com/news/2018/may-23rd/nakpaa-naa-family-sad-but-accepts-sc-court-rulingon-bimbilla-skin.php

Ghana, Chieftaincy Act, Act 759. Accra: Assembly Press, 2008.

Ghana, Constitution of the Republic of Ghana. Accra: Assembly Press, 1992.

Ghana, Alternative Dispute Resolution Act, Act 798. Accra: Assembly Press, 2010

Ghana Business News, "352 chieftaincy disputes remain unresolved in Ghana." 2017.Accessed April 27, 2021.

https://www.ghanabusinessnews.com/2017/06/01/352-chieftaincy-disputes-remain-unresolved-in-ghana/.

GNA, "The Chieftaincy Institution is still Relevant," Ghana News Agency, April 26, 2010. http://ghananewsagency.org/social/the-chieftaincy-institution-is-still-relevant--14879

GNA, Chiefs have ensured peace in the country through customary arbitration-Asum Ahensah. Ghana News Agency, October 27, 2010. https://www.businessghana.com/site/news/general/122957/Chiefs-have-ensured-peace-inthe-country-through-customary-arbitration-Asum-Ahensah.

Hagan, George Panyin "Epilogue: The Way Forward-New Wines and Broken Bottles” In Chieftaincy in Ghana: Culture, Governance and Development, edited by Irene Odotei and Albert K. Awedoba, 663-673. Accra: Sub-Saharan Publishers, 2006.

Stephen B. Kendie, Patrick Osei-Kufuor and Kwaku Adutwum Boakye, eds., Spatial analysis of violent conflicts in Ghana: 2007-2014. Cape Coast: Faculty of Social Sciences, 2014.

Lartey, Philip Nii. "Chieftaincy disputes disrupting our lives-Oshiyie residents." citifmonline, August 8, 2017. http://citifmonline.com/2017/08/18/chieftaincy-dispute-disrupting-our-lives-oshieyie-residents/

Onyema, Emelia "The new Ghana ADR Act 2010: A critical overview." Arbitration Journal, 28 no. I (2012): 101-124.

Owusu-Mensah, Isaac; Asante, W and Osew, W.K. "Queen Mothers: The unseen hands in Chieftaincy conflicts among the Akan in Ghana: Myths or reality," The Journal of Pan African Studies, 8 no. 6 (2015): 1-16.

Tonah, Steve "The Politicisation of a Chieftaincy Conflict: The Case of Dagbon, Northern Ghana," Nordic Journal of African Studies, 21 no. 1 (2012): 1-20.

Valsecchi, Pierliugi. "He who sets Boundaries: Chieftaincy as a necessary institution in modern Ghana," Department of Communication Working Paper, no 3 (2007): 1-28.

Ward, Dorothy Frances. "NHC upset about flare up of Bimbilla and Ga Chieftaincy conflicts." Ghana News Agency, February 14, 2017. http://www.ghananewsagency.org/print/113257 